\title{
The effect of differences between house length and placement zones inside the closed house on the utilization of broiler chicken feed protein in the dry season
}

\author{
Arjanggi Ari Bimo1), Teysar Adi Sarjana*1) and Edjeng Suprijatna ${ }^{1)}$ \\ ${ }^{1)}$ Faculty of Animal and Agricultural Sciences, Diponegoro University, Semarang \\ Jl. Prof. H. Soedarto, S.H. - Tembalang Semarang, Indonesia, 50275
}

Submitted: 06 December 2019, Accepted: 29 September 2020

\begin{abstract}
The research aims to examine the effect of differences in house length and placement zones inside a closed house on the utilization of broiler chicken feed protein in the dry season. The research material is 600 broiler chickens (strain cobb) divided into 20 experimental units and 2 closed houses with a length of $60 \mathrm{~m}$ with a capacity of 11,000 and a length of $120 \mathrm{~m}$ with a capacity of 22,000. This research used a randomized block design with a split-plot pattern and two factors. The main plot is closed house with length 60 and 120 meters, the subplot is the zone placement of chicken which are divided into 4 zones: zone 1 is parallel to the inlet, zone 2 is measured at $1 / 4$ of the house length, zone 3 is measured at $1 / 2$ the house length, zone 4 is measured at 3/4 the house length from the inlet. The parameters observed were protein digestibility, the protein efficiency ratio (PER), and nitrogen retention (NR). Macroclimate, microclimate, and microclimatic ammonia observed as supporting data and an overview of the research conditions. Longer house and placement zone of chicken further from the inlet increase temperature, humidity, and microclimatic ammonia inside the closed house. The results showed an interaction between the house length and placement zone of chicken against NR. The housing length of $120 \mathrm{~m}$ and zone 4 was significantly $(P \leq 0,05)$ having lower protein digestibility, PER, and NR values. Protein digestibility began to decrease significantly $(\mathrm{P} \leq 0,05)$ in zone 3 , while PER and NR significantly decrease from zone 2 . It concludes that longer closed house and placement zones further from the inlet decrease the ability of broilers to utilizing feed protein in the dry season.
\end{abstract}

Keywords: House length; Placement zones; Protein digestibility; PER; Nitrogen retention; Broiler.

*Corresponding Author: teysaradisarjana@lecturer.undip.ac.id 


\section{INTRODUCTION}

Closed house is closed ones equipped with modern technology and are designed to be able to regulate microclimates that are suitable for chickens and provide quality air by flowing hot air, releasing gases (ammonia and carbon dioxide) that can be used when repairing chickens (Metasari et al., 2014). The microclimate conditions are related to the macroclimate conditions, meaning the difference in seasons determines the microclimate conditions.

The dry season in Semarang in April 2017 has an average temperature of $32,27^{\circ} \mathrm{C}$, while in April 2018 it increased by 2,9\% with average temperature reaching $33,23^{\circ} \mathrm{C}$ (BMKG, 2018). The size of a closed house is directly proportional to the density, capacity of chickens and microclimate conditions, the longer and wider the size, means that the more chicken population, resulting in an increase in temperature, humidity, wind speed and ammonia levels in the closed house (Renata et al., 2018). The placement or pen zone distribution system is applied as a standard in the maintenance of broiler chickens in a closed house, aimed at leveling the distribution of feed and drinking water and preventing the buildup of chickens in certain places. However, the system has an impact on microclimate conditions and ammonia levels in the closed house (Sarjana et al., 2018). Changes in temperature, humidity, and ammonia levels in the closed house that increase along with the placement zone of chickens further from the inlet in the dry season. Changes in microclimate conditions were followed by an increase in ammonia production from 1,57 to $6,22 \mathrm{ppm}$ as the zone was farther from the inlet (Renata et al., 2018).

Changes in microclimate conditions lead to increased levels of ammonia in a closed house (Nassem and King, 2018). This increase will experience fluctuations in each zone called microclimatic ammonia (Miles et al., 2006) and is a source of stressors for broiler chickens. The form of stressors in the form of respiratory tract infections (Shi et al., 2019), failure of thermoregulation (Tamzil, 2014) and followed by changes in the ratio of heterophyll lymphocytes and the number of leukocytes in the blood (Kusnadi and Rahim, 2009; Sulaibah et al., 2019) are problems that often occur in broiler chickens. The change in $\mathrm{H} / \mathrm{L}$ ratio is one indicator of oxidative stress (Lin et al., 2006) where there is a reactive element that exceeds the capacity of antioxidant cells in the chicken body (Akbarian et al., 2016). Oxidative stress caused by changes in ammonia microclimate and microclimatic conditions in the closed house and different chicken placement zones in the dry season has an impact on decreased feed consumption and metabolic response, thereby affecting feed digestibility.

Decreased digestibility of broiler chicken feed protein due to stress by 12 $55 \%$ at temperatures of $21^{\circ} \mathrm{C}-32^{\circ} \mathrm{C}$ (Zuprizal et al., 1993; Puvaldolpirod and Thaxton, 2000), because there is an inhibition of the movement of the digestive tract (Hai et al., 2000) and enzyme activity protein digesters (Osman and Tanios, 1983), besides effluent the secretion of various hormones (Sugito et al., 2007) one of the hormones associated with protein digestion is T3, where the circulation of the T3 hormone (tri-iodothyronine hormone) in the blood decreases (Tamzil, 2014). The disruption of hormone secretion and enzyme activity has an impact on the inhibition of the process of absorption of feed protein, resulting in a decrease in feed protein efficiency by $4-10 \%$ and the growth rate of broiler chickens (Brilianto et al., 2019; Beker et al., 2004; Homidan et al., 2003). If feed efficiency decreases, the PER value is low due to reduced protein consumption and broiler chicken body weight gain (Herdiana et al., 2014). Nitrogen retention will also decrease when protein consumption and protein digestibility are not optimal (Indrasari et al., 2014). This research aims to examine the effect of differences in house lengths and placement zones in a closed house on the utilization of broiler chickens 
feed protein in the dry season. The benefit of this research is to provide information about the effect of different lengths and the placement zones in the closed house on the utilization of broiler chickens feed protein in the dry season. The research hypothesis is that the longer the house and the zone farther from the inlet will reduce the level of utilization of feed protein in broiler chickens in the dry season.

\section{MATERIALS AND METHODS}

The research was done during the dry season on two closed-house units, each measuring $60 \mathrm{~m} \times 12 \mathrm{~m}$ wide by 11,000 broilers and $120 \mathrm{~m} \times 12 \mathrm{~m}$ wide by 22,000 broilers. The closed house model is negative pressure where air moves in one direction, entering through the inlet and exiting through the outlet. Day Old Chicken (DOC) unsexed broiler chickens, Cobb strains with an average initial weight of 46,76 $\pm 2,83$ grams. The commercial feed from PT. Charoen Pokphand gave during maintenance (28 days) there are 3 types, namely S-10 (0-10 days), S-11 (11-20 days), and S-12 (21-28 days) with the nutrient content presented in Table 1.

The study used a randomized block design with split plot pattern, house length as the main plot, and chicken placement zone as a subplot. The treatment consists of two factors, the first factor is the length of the house (60 and 120 meters) and the second factor is the placement zone of the chicken in the house which is divided into 4 zones namely zone 1 parallel to the inlet, zone 2 is measured at $1 / 4$ the length of the house from the inlet, zone 3 is measured at $1 / 2$ the length of the house from the inlet, zone 4 is measured at 3/4 length of the house from the inlet.

Table 1. Proximate Analysis Results of the Diet Nutrient Content

\begin{tabular}{llllllll}
\hline \multirow{2}{*}{ Feed types } & \multicolumn{7}{c}{ Kandungan Nutrien } \\
\cline { 2 - 8 } & $\begin{array}{l}\text { Water } \\
\text { Content }\end{array}$ & $\begin{array}{l}\text { Crude } \\
\text { Protein }\end{array}$ & $\begin{array}{l}\text { Crude } \\
\text { Fat }\end{array}$ & $\begin{array}{l}\text { Crude } \\
\text { Fiber }\end{array}$ & Calcium & \multirow{2}{*}{ Phosphor } & $\begin{array}{l}\text { Metabolic } \\
\text { Energy* }\end{array}$ \\
\hline S-10 & 7,33 & 22,97 & 8,00 & 3,26 & 0,97 & 0,72 & 3351 \\
S-11 & 8,50 & 22,60 & 7,50 & 3,11 & 0,90 & 0,66 & 3355 \\
S-12 & 9,17 & 22,38 & 7,00 & 3,05 & 0,82 & 0,50 & 3327 \\
\hline
\end{tabular}

Source: *Calculations based on the Bolton formula as used in Sugiharto et al. (2017).

The total excreta collection method plus feed indicator is used to measure chicken protein digestibility. At the age of 28 days, one broiler chicken was taken from each unit representing each treatment, then placed in a battery cage with a place to feed and drink installed in the house, fasted from feed for 12 hours after that the chickens were given indicator feed, namely type S-12 feed that has been weighed and added $\mathrm{Fe} 2 \mathrm{O} 3$, then excreta is stored for 24 hours as analytical data, sprayed with $0,1 \mathrm{~N}$ HCL every 4 - 6 hours (Wahju, 2004). Finally, feed consumption is recorded, excreta is taken, weighed (wet weight) and air-dried, re-weighed (dry weight), and then analyzed in the laboratory. Analysis carried out to measure the utilization of feed protein is an analysis of protein content and water content of feed used to estimate the actual levels of feed protein by knowing the dry matter of feed based on AOAC (2005), after which protein digestibility is calculated (McDonald et al., 1988), PER (Anggorodi, 1994) and NR (Wolynetz and Sibbald, 1984): 
1. Digestibility Protein Formula:

Protein Digestibility $(\%)=\frac{\text { Protein consumed }- \text { Excreta protein }}{\text { protein consumed }(\mathrm{g})} \times 100 \%$

Note:

Protein consumed $\quad=$ feed consumed $(\mathrm{g}) \times$ feed protein levels $(\%)$

Excreta protein $\quad=70 \% \mathrm{x}$ excreta protein, because uric acid levels in the excreta assumed to be urine is $30 \%$ excreta (Wahju, 2004).

2. Protein Efficiency Ratio Formula:

Protein Efficiency Ratio $=\frac{\text { daily weight gain }(\mathrm{g})}{\text { protein consumed }(\mathrm{g})}$

3. Nitrogen Retention Formula:

Nitrogen Retention $(\mathrm{g}) \quad=$ consumed $\mathrm{N}(\mathrm{g})-\operatorname{excreta} \mathrm{N}(\mathrm{g})$

Note :

Consumption $\mathrm{N} \quad=$ amount of consumption $(\mathrm{g}) \times$ feed $\mathrm{N}$ level $(\%)$

Excreta $\mathrm{N} \quad=$ amount of excreta $(\mathrm{g}) \times$ excreta $\mathrm{N}$ level $(\%)$

Table 2. Average Condition of Macroclimate and Microclimate of Closed House During Maintenance Period

\begin{tabular}{|c|c|c|c|c|c|}
\hline Macroclimate* & & & Value & & \\
\hline Temperature $\left({ }^{\circ} \mathrm{C}\right)$ & & & 27,00 & & \\
\hline Humidity (\%) & & & 80,10 & & \\
\hline Wind Speed (m/s) & & & 1,50 & & \\
\hline Rainfall (mm) & & & 2,70 & & \\
\hline Sun Radiation $\left(\mathrm{W} / \mathrm{m}^{2}\right)$ & & & 264,50 & & \\
\hline Microclimate & Closed house & Zone 1 & Zone 2 & Zone 3 & Zone 4 \\
\hline \multirow[t]{2}{*}{ Ammonia (ppm) } & $60 \mathrm{~m}$ & 1,29 & 2,38 & 3,71 & 4,46 \\
\hline & $120 \mathrm{~m}$ & 2,26 & 4,06 & 5,83 & 6,45 \\
\hline \multirow{2}{*}{ Temperature $\left({ }^{\circ} \mathrm{C}\right)$} & $60 \mathrm{~m}$ & 29,27 & 29,85 & 29,95 & 30,29 \\
\hline & $120 \mathrm{~m}$ & 28,81 & 29,55 & 29,91 & 30,36 \\
\hline \multirow[t]{2}{*}{ Humidity (\%) } & $60 \mathrm{~m}$ & 82,76 & 82,95 & 83,08 & 83,54 \\
\hline & $120 \mathrm{~m}$ & 82,93 & 83,54 & 83,62 & 83,80 \\
\hline \multirow[t]{2}{*}{ Wind Speed (m/s) } & $60 \mathrm{~m}$ & 2,05 & 1,40 & 1,36 & 1,30 \\
\hline & $120 \mathrm{~m}$ & 1,86 & 1,78 & 1,71 & 1,61 \\
\hline \multirow[t]{2}{*}{ Heat Stress Index } & $60 \mathrm{~m}$ & 167,45 & 168,68 & 168,98 & 170,06 \\
\hline & $120 \mathrm{~m}$ & 166,79 & 168,73 & 169,46 & 170,45 \\
\hline
\end{tabular}

Note: *Macroclimate based on data from the Automatic Weather Station of Meteorological, Climatological, and Geophysical Agency (BMKG) which placed in FPP, UNDIP. 2018.

The way to find out nitrogen feed levels is to calculate feed protein levels divided by 6,25 . Because it is assumed that the amount of nitrogen contained in proteins is constant at $16 \%$. The change gradient value of each parameter is also calculated based on the difference in the decrease of each parameter between each treatment and expressed as a percentage to provide a more detailed picture related to changes in protein utilization that occur due to different house lengths and placement zones. Measurement of the microclimate and macroclimate conditions of the closed house every day at $05.00,13.00$ and 21.00 WIB include temperature, humidity and wind speed using a kestrelTM tool and microclimatic measurements of ammonia using an 
ammonia detector and for the Heat Stress Index (HSI) calculated by the formula HSI = ${ }^{\circ} \mathrm{F}+\% \mathrm{RH}$ and temperature ${ }^{\circ} \mathrm{F}=\left(9 / 5 \mathrm{x}{ }^{\circ} \mathrm{C}\right)$ $+32^{\circ} \mathrm{C}$ (Aviagen, 2010). The data obtained is used as supporting data and a description of the research conditions. Data on closedhouse macroclimate and microclimate conditions are presented in Table 2.

The data obtained were then processed statistically by analysis of variance (ANOVA) with the F test at level $\alpha \leq 5 \%$, and significantly different data were further tested by the DMRT test.

\section{RESULT AND DISCUSSION}

The results of the analysis of the variability of protein digestibility, PER, and nitrogen retention (NR) are presented in table 3. There was an interaction $(\mathrm{P}>0,05)$ between the length and the chicken placement zones on the NR, but there was no interaction $(\mathrm{P}>0,05)$ of the treatment effect on protein digestibility and protein efficiency ratio. Broilers in a closed house of 60 meters and inlet-parallel zones have better digestibility of protein, PER, and NR. Longer closed house and farther zones from the inlet significantly reduce the digestibility of feed protein, PER, and NR of broiler chickens.

\section{Protein Digestibility}

The results of the analysis of variance showed no significant interaction $(\mathrm{P}>0,05)$ between the differences of house length and placement zones on the feed protein digestibility of broiler chickens. The placement zone of chicken further from the inlet has a significant effect $(\mathrm{P} \leq 0,05)$ on the decrease in feed protein digestibility of broiler chickens.

Tabel 3. Average of Broiler Chicken Feed Protein Utilization Due to Different House Length and Placement Zones.

\begin{tabular}{lcccc}
\hline \multirow{2}{*}{ Parameter } & & Protein Digestibility & PER & Nitrogen Retention \\
\cline { 3 - 5 } Closed house 60 m & Zone 1 & 85,42 & 3,74 & $(\mathrm{~g})$ \\
& Zone 2 & 79,60 & 3,62 & $1,68^{\mathrm{c}}$ \\
& Zone 3 & 74,10 & 3,55 & $1,00^{\mathrm{e}}$ \\
Closed house 120 & Zone 4 & 73,37 & 3,54 & $0,63^{\mathrm{e}}$ \\
$\mathrm{m}$ & Zone 1 & 78,51 & 3,47 & $2,85^{\mathrm{a}}$ \\
& Zone 2 & 77,83 & 3,31 & $2,17^{\mathrm{b}}$ \\
Closed house & Zone 3 & 72,19 & 3,25 & $1,17^{\mathrm{de}}$ \\
\multirow{3}{*}{ Zone } & Zone 4 & 68,57 & 3,22 & $1,59^{\mathrm{c}}$ \\
& $60 \mathrm{~m}$ & 78,12 & $3,61^{\mathrm{X}}$ & 1,20 \\
& $120 \mathrm{~m}$ & 74,28 & $3,31^{\mathrm{Y}}$ & 1,95 \\
P Value & 1 & $81,96^{\mathrm{X}}$ & $3,60^{\mathrm{X}}$ & 2,27 \\
& 2 & $78,72^{\mathrm{XY}}$ & $3,47^{\mathrm{Y}}$ & 1,59 \\
& 3 & $73,14^{\mathrm{Y}}$ & $3,40^{\mathrm{Z}}$ & 1,33 \\
& 4 & $70,97^{\mathrm{Y}}$ & $3,38^{\mathrm{Z}}$ & 1,11 \\
& interaction & 0,92 & 0,72 & $0,00^{*}$ \\
& house & 0,15 & $0,00^{*}$ & $0,00^{*}$ \\
& zone & $0,03^{*}$ & $0,00^{*}$ & $0,00^{*}$ \\
\hline
\end{tabular}

Note: - superscript uppercase letters notation $(\mathrm{X}, \mathrm{Y}, \mathrm{Z})$ showing real differences $(\mathrm{P} \leq 0,05)$ on subplot or main plot

- superscript lowercase notation $(a, b, c)$ indicates the interaction between treatments - * = significant $(\mathrm{P} \leq 0,05)$ on main plot or sub plot 


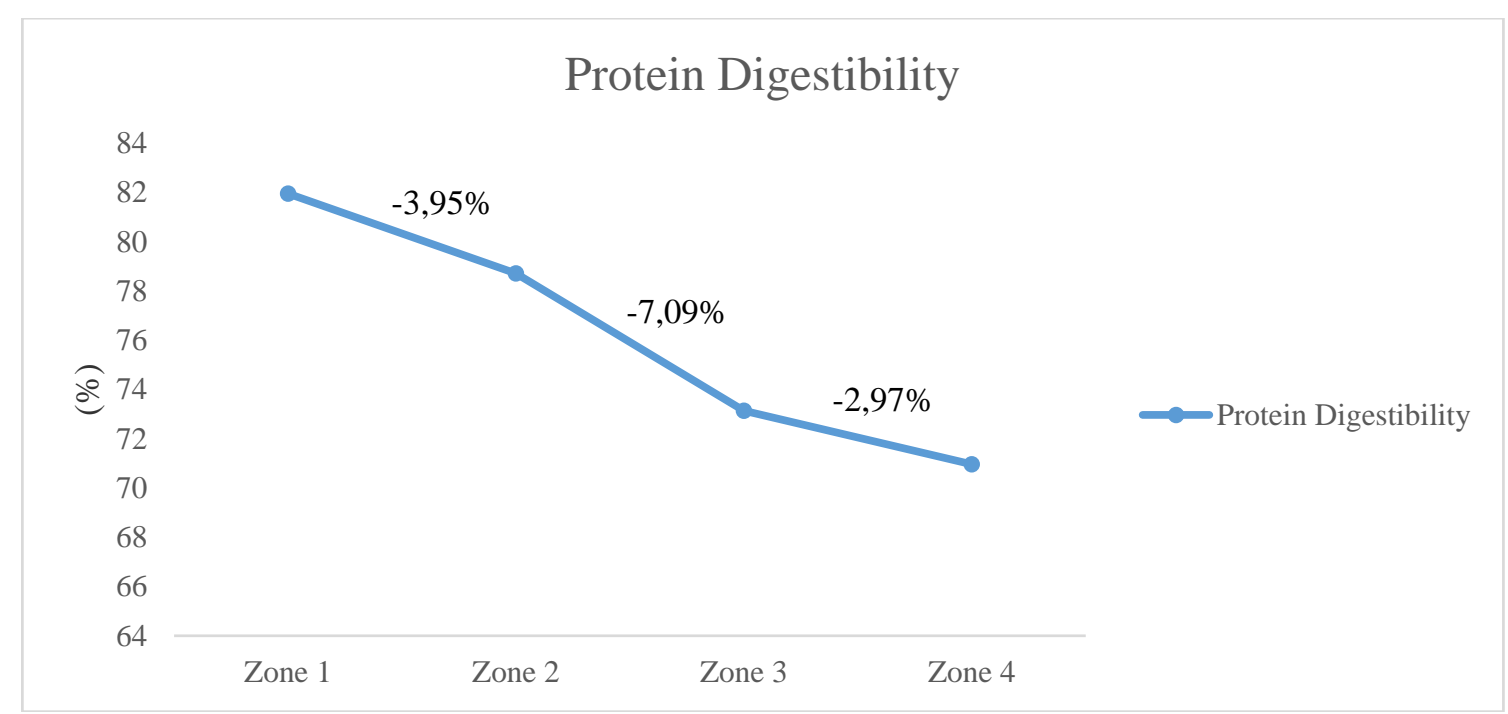

Illustration 1. Gradient Decrease of Broiler Chicken Protein Digestibility.

Based on the data presented in Table 3 shows that decreased digestibility of broiler chicken feed protein began to occur significantly $(\mathrm{P} \leq 0,05)$ in zone 3 . Longer closed house and zones for further retention of inlet increased microclimatic ammonia by about $30 \%$ and absolute temperature around $5 \%$ as presented in table 2 , this increase in this study has the potential to cause oxidative stress.

One indicator when chickens experience oxidative stress is indicated by changes in the number of leukocytes and $\mathrm{H}$ / $\mathrm{L}$ ratio in the body measured in the same study, published by Sulaibah et al., (2019) that an increase in oxidative stress in a chicken's body is indicated by a decrease in $\mathrm{H} / \mathrm{L}$ ratio of $38,15 \%$ and the number of leukocytes of $25,61 \%$ in the zone further from the inlet. Another indicator of oxidative stress is a change in the decrease in the red blood profile of around 8,6\% (Sarjana et al., Unpublished). The results of the analysis of variance showed no significant interaction effect $(\mathrm{P}>0,05)$ between the different house length and placement zones on the digestibility of broiler chicken feed protein.

The placement zone of chicken further from the inlet has a significant effect $(\mathrm{P} \leq 0,05)$ on the decrease in protein digestibility of broiler chicken feed. Ammonia microclimate and microclimatic changes in different house and placement zones (Table 2.) are thought to also cause oxidative stress. This is in accordance with the research of Brilianto et al., (2019) which states that ammonia accumulation which increases as the zone is farther from the inlet, will trigger stress and have an impact on reducing the level of consumption and protein absorption of broiler chicken feed. Heat stress index (HSI) in the temperature range $28-31^{\circ} \mathrm{C}$ decreases metabolic responses such as protein digestion, the release of $\mathrm{T} 3$ hormone and digestive enzyme activity is disrupted. T3 hormone and protein digestive enzymes associated with the level of feed protein digestibility of chickens. This is supported by the opinion of Yahav and Mcmurtry (2001) which states that the release of hormones such as T3 and digestive enzymes is disturbed due to stress experienced by chickens. T3 hormone functions as a stimulant for the digestive organs to release protein decomposing enzymes (proteases) and increase metabolic processes such as the degradation of feed proteins (Tamzil, 2014).

Degradation of feed protein by cells for various reasons such as basic living needs, tissue growth, repair of damaged cells, and weight gain. Oxidative stress that occurs due to changes in ammonia microclimate and microclimatic conditions is thought to affect the metabolic process, namely the digestibility of feed protein. This is consistent with the opinion of Yahav 
(2004) which states that the degradation of feed protein in the chicken body is influenced by temperature, the humidity of the closed house, the water content of excreta, and air ammonia. Decreased digestibility of feed nutrients in stressed broiler chickens can reach $55 \%$ (Puvaldolpirod and Thaxton, 2000). Other studies of oxidative stress have an impact on decreased appetite, decreased protein digestibility by $5-12 \%$ at temperatures from $21^{\circ} \mathrm{C}$ to $32^{\circ} \mathrm{C}$ and followed by inhibition of movement of the digestive tract (Hai et al., 2000; Zuprizal et al., 1993).

\section{Nitrogen Retention}

Statistical results show that there is a significant interaction effect $(\mathrm{P}>0,05)$ between different length and placement zone of the closed house to nitrogen retention. Significant nitrogen retention value $(\mathrm{P} \leq 0,05)$ was greater in zone 1 in both closed house and there was a significant decrease $(\mathrm{P} \leq 0,05)$ in the chicken placement zone farther from the inlet. Based on the results obtained, the nitrogen retention value of broilers placed in closed houses of a certain length depends on the placement zone.

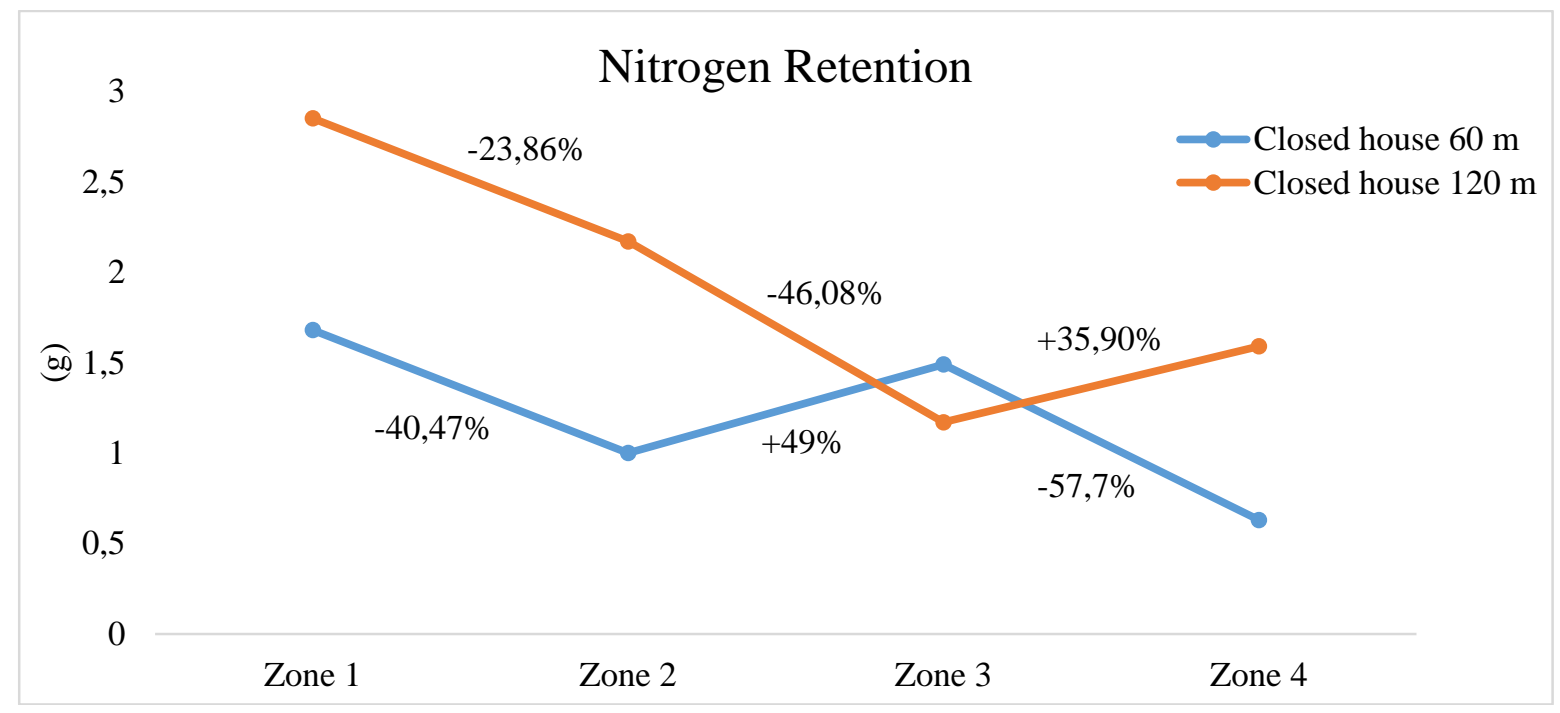

Illustration 2. Gradient Decrease of Broiler Chicken Nitrogen Retention.

Based on the data in table 3. nitrogen retention (NR) is highest in zone 1 and begins to decrease in zone 2 . The average NR of broiler chickens is around 1,50-1,73 $\mathrm{g} / \mathrm{head} /$ day (MacLeod et al., 1988) or 70 $80 \%$ of total nitrogen consumption. The decrease in NR is thought to be caused by an increase in ammonia microclimate and microclimatic as the zone is farther from the inlet. Increased ammonia results in oxidative stress. These conditions make the metabolic process inhibited, including the process of breaking down proteins into simpler compounds and decreased digestion of feed protein, so chickens are less optimal in retaining nitrogen. This is in accordance with the opinion of Bonnet et al. (1997) that chickens experiencing stress due to temperature increase will decrease NR around $8-9 \%$. Increased ammonia in the zone further from the inlet causes changes in chicken physiological conditions and leads to oxidative stress. Oxidative stress in chickens is thought to reduce the ability of protein absorption in the digestive tract used for tissue and cell growth, so chicken growth is not optimal.

The process of absorption of feed protein, associated with NR. Nitrogen retention is the amount of nitrogen stored or retained in the body and not excreted with excreta, which means the higher the nitrogen contained in the excreta, the higher the ammonia produced from the excretion process of nitrogen excretion by ureolytic bacteria (Patterson and Adrizal, 2005). The process of absorption of feed protein is disrupted, the NR value will decrease. This 
is consistent with the opinions of Fanani et al. (2014) which states that an increase in protein digestibility and digestibility will cause an increase in NR that can be utilized by the body thereby affecting an increase in body weight.

\section{Protein Efficiency Ratio (PER)}

Statistical results showed no significant interaction effect $(\mathrm{P}>0,05)$ between the different lengths and the placement zones on PER of broiler chickens. The treatment of a longer closed house and the zone of placement of chickens farther from the inlet has a significant effect $(\mathrm{P} \leq 0,05)$ on the decrease in PER. Based on table 3. that a decrease in the value of PER began to occur in zone 2. The highest PER was seen in zone 1 or parallel to the inlet and the lowest in zone 4. Whereas, the standard PER value for broiler chickens ranged from 3,24 - 2,34 (Selle et al., 2003). PER is influenced by protein consumption and body weight gain. The results showed a decrease in the value of PER.
A. Effects of House on PER

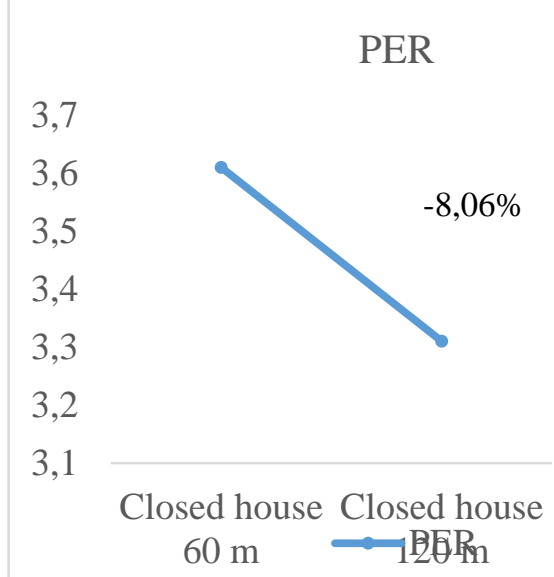

B. Effects of Placement Zones on PER

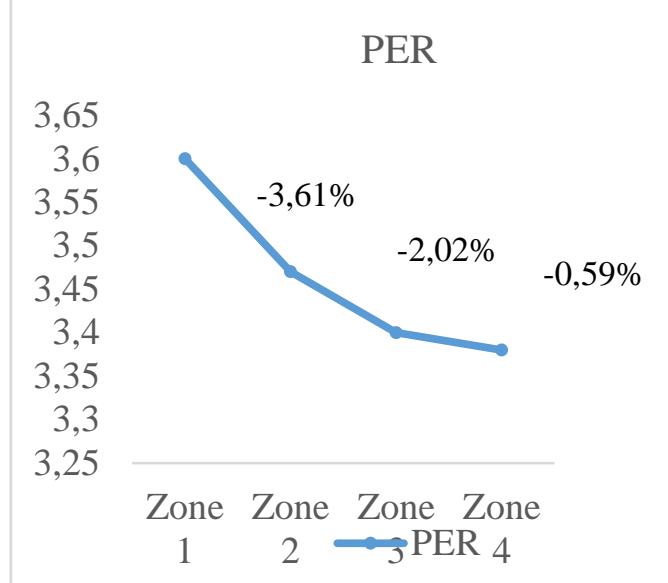

Illustration 3. Gradient Decrease of Broiler Chicken Protein Efficiency Ratio (PER).

The longer the width of the house, the lower the ammonia gas production as well as the zone of the house. Increased ammonia at a certain level can reduce the consumption of feed protein, interfere with the digestibility of feed protein and low protein efficiency. This is consistent with the opinion of Ritz et al. (2004) that NH3 or ammonia levels above $25 \mathrm{ppm}$ in the house can reduce feed efficiency, increase body weight and irritate the respiratory tract in chickens.

Ammonia which is toxic and has a strong odor has the potential to reduce feed consumption by $1-5 \%$ and irritate the respiratory tract. According to the study of Xiong et al., (2016) that ammonia with a concentration of around $75 \mathrm{ppm}$ caused a decrease in average feed intake of about $5,7 \%$ and a decrease in body weight $16,4 \%$ and chronic damage to the tracheal and intestinal lesions. Other studies also mention that ammonia concentrations above $25 \mathrm{ppm}$ cause a decrease in feed efficiency by $10 \%$, feed consumption, and body weight. (Ritz et al., 2004; Homidan et al., 2003). Inefficiency absorption of feed protein certainly has an impact on the result in the form of chicken body weight. This is consistent with the opinion of Mahfudz (2006) which states that the PER is in line with PBBH which means that chickens efficiently utilize feed protein to form body tissue or meat, if bodyweight does not reach the target will be followed by a low PER value. A decrease in the value of PER is characterized by a decrease in body weight gain of about $1,4-1,7 \%$ during the maintenance period in the chicken placement zone further from the inlet (Sarjana et al., Unpublished).

In a study conducted by factors other than microclimatic ammonia in the form of differences in microclimate conditions at 
different lengths and different placement zones, it is thought to be insufficient to make a strong enough contribution to changes in the ability of protein utilization. Although, in the same study (Endraswati et al., 2019), there was a $5 \%$ increase in humidity and a temperature of $1^{\circ} \mathrm{C}$ in the zone further from the inlet. This increase results in a decrease in the effectiveness of thermoregulation in the zone further from the inlet because of the potential to irritate the respiratory tract and cause oxidative stress. The results of previous studies carried out in the same closed-house show the contribution of ammonia microclimatic changes to performance (feed consumption, BWG, and FCR) is greater than the HSI (heat stress index) of broiler chickens which is an indicator of the utilization of broiler chicken feed protein (Angkeke et al., 2018). Changes in HSI values depend on microclimate conditions (temperature and humidity) at different house length and placement zones.

\section{CONCLUSIONS}

Broiler chickens that are maintained in closed houses with a length of $120 \mathrm{~m}$ and the placement zone further from the inlet are worse in utilizing protein feed than the closed house of $60 \mathrm{~m}$ and the placement zone is parallel to the inlet in the dry season. Closed house with a length of $120 \mathrm{~m}$ and a placement zone further from the inlet decreases nitrogen retention. Broiler chickens that are maintained in closed houses $120 \mathrm{~m}$ have lower protein digestibility than chickens in closed houses $60 \mathrm{~m}$. Chickens that are maintained in a closed house $120 \mathrm{~m}$ and zones further from the inlet have a lower PER than chickens in closed houses $60 \mathrm{~m}$ and are placed in zones parallel to the inlet.

\section{REFERENCES}

Akbarian, A., Michiels, J., Degroote, J., Majdeddin, M., Golian, A., \& De Smet, S. (2016). Association between heat stress and oxidative stress in poultry; mitochondrial dysfunction and dietary interventions with phytochemicals. Journal of Animal Science and Biotechnology, 7(1), 114. https://doi.org/10.1186/s40104016-0097-5

Anggorodi, R. (1994). Nutrisi Aneka Ternak Unggas. PT Gramedia Pustaka Utama.

Angkeke, I. P., Sarjana, T. A., \& Suprijatna,

E. (2019). The influence of microclimatic ammonia changes in closed house on broiler's performance in dry season. Animal Production, 20(2), 125-131. https://doi.org/10. 20884/1.jap.2018.20.2.695

Association of Analytical Communities. (2005). Official Methods of Analysis. In Eighteenth edition. Association of Official Analytical Chemists. Benjamin Franklin Station.

Aviagen. (2010). Ross Environmental Management in the Broiler House.

Badan Meteorologi, Klimatologi, dan G. (2018). Perubahan Iklim: Tren Suhu.

Beker, A., Vanhooser, S. L., Swartzlander, J. H., \& Teeter, R. G. (2004). Atmospheric Ammonia concentration effects on broiler growth and performance. Journal of Applied Poultry Research, 13(1), 5-9. https://doi.org/10.1093/japr/13.1.5

Bonnet, S., Geraert, P., Lessire, M., Carre, B., \& Guillaumin, S. (1997). Effect of high ambient temperature on feed digestibility in broilers. Poultry Science, 76(6), 857-863. https://doi. org/10.1093/ps/76.6.857

Brilianto, I., Sarjana, T. A., \& Murwani, R. (2019). Pengaruh zonasi dalam kandang closed house terhadap profil darah merah ayam broiler. Jurnal Peternakan Indonesia, 21(2), 59-63. https://doi.org/10.25077/jpi.21.2.5963.2019

Endraswati, A., Mahfudz, L. D., \& Sarjana, T. A. (2019). Kontribusi faktor klimat di luar kandang terhadap perubahan mikroklimat closed house dengan panjang berbeda pada periode brooder di musim kemarau. Jurnal Agripet, 19(1), 59-67. https://doi.org/10.1796 9/agripet.v19i1.13918 
Fanani, A. F., Suthama, N., \& Sukamto, B. (2017). Retensi nitrogen dan konversi pakan ayam lokal persilangan yang diberi ekstrak umbi dahlia (Dahlia variabilis) sebagai sumber inulin. Sains Peternakan, 13(2), 69-75. https://doi.org/10.20961/sainspet.v12i 2.4762

Hai, L., Rong, D., \& Zhang, Z.-Y. (2000). The effect of thermal environment on the digestion of broilers. Journal of Animal Physiology and Animal Nutrition, 83(2), 57-64. https://doi.org/ 10.1046/j.1439-0396.2000.00223.x

Herdiana, R. M., Marshal, Y., Dewanti, R., \& Sudiyono, S. (2014). Pengaruh penggunaan ampas kecap dalam pakan terhadap pertambahan bobot badan harian, konversi pakan, rasio efisiensi protein, dan produksi karkas itik lokal jantan umur delapan minggu. Buletin Peternakan, 38(3), 157-162. https://doi.org/10.21059/buletinpetern ak.v38i3.5251

Homidan, A., Al, Robertson, J. F., \& Petchey, A. M. (2003). Review of the effect of ammonia and dust concentrations on broiler performance. World's Poultry Science Journal, 59(3), 340-349. https://doi. org/10.1079/WPS20030021

Indrasari, F. N., Yunianto, V. D., \& Mangisah, I. (2014). Evaluasi kecernaan protein kasar dan retensi nitrogen pada ayam broiler dengan ransum berbeda level protein dan asam asetat. Animal Agriculture Journal, 3(3), 401-408.

Kusnadi, E., \& Rahim, F. (2009). Performa dan kandungan hormon triiodotironin plasma ayam broiler akibat pengaruh cekaman panas di daerah tropis. Media Peternakan, 32(3), 155-161. https:// doi.org/10.5398/medpet.v32i3.1125

Lin, H., Decuypere, E., \& Buyse, J. (2006). Acute heat stress induces oxidative stress in broiler chickens. Comparative Biochemistry and Physiology Part A: Molecular \& Integrative Physiology, 144(1), 11-
17. https://doi.org/10.1016/j.cbpa.200 6.01 .032

MacLeod, M. G., Whitehead, C. C., Griffin, H. D., \& Jewitt, T. R. (1988). Energy and nitrogen retention and loss in broiler chickens genetically selected for leanness and fatness. British Poultry Science, 29(2), 285-292. https://doi.org/10.1080/00071668808 417053

Mahfudz, L. (2006). Pengaruh penggunaan ampas tahu fermentasi terhadap efisiensi penggunaan protein itik tegal jantan. Journal of the Indonesian Tropical Animal Agriculture, 2(31), 129-134.

McDonald, P. A., Edwards, \& Green Haigh, J. F. D. (1988). Animal Nutrition. In Longman Scientific and Technical (4th ed.). Copublishing in The USA with John Wiley and Sons. Inc.

Metasari, T., Septinova, D., \& Wanniatie, V. (2014). Pengaruh berbagai jenis bahan litter terhadap kualitas litter broiler fase finisher di closed house. Jurnal Ilmiah Peternakan Terpadu, 2(3), 23-29. https://doi.org/10.23960/jipt.v2i3. 498

Miles, D. M., Owens, P. R., \& Rowe, D. E. (2006). Spatial variability of litter gaseous flux within a commercial broiler house: ammonia, nitrous oxide, carbon dioxide, and methane. Poultry Science, 85(2), 167-172. https://doi. org/10.1093/ps/85.2.167

Naseem, S., \& King, A. J. (2018). Ammonia production in poultry houses can affect health of humans, birds, and the environment - techniques for its reduction during poultry production. Environmental Science and Pollution Research, 25(16), 15269-15293. https: //doi.org/10.1007/s11356-018-2018-y

Osman, A. M., \& Tanios, N. I. (1983). The effect of heat on the intestinal and pancreatic levels of amylase and maltase of laying hens and broilers. Comparative Biochemistry and Physiology Part A: Physiology, 75(4), 563-567. https://doi.org/10.1016/030 0-9629(83)90421-8 
Patterson, P. H., \& Adrizal. (2005). Management strategies to reduce air emissions: emphasis-dust and ammonia. Journal of Applied Poultry Research, 14(3), 638-650. https://doi. org/10.1093/japr/14.3.638

Puvadolpirod, S., \& Thaxton, J. P. (2000). Model of physiological stress in chickens 4. Digestion and metabolism. Poultry Science, 79(3), 383-390. https://doi.org/10.1093/ps/79.3.383

Renata, R., Sarjana, T. A., \& Kismiati, S. (2018). Pengaruh zonasi dalam kandang closed house terhadap kadar amonia dan dampaknya pada kualitas daging broiler di musim penghujan. Jurnal Ilmu-Ilmu Peternakan, 28(3), 183-191. https://doi.org/10.21776/ub. jiip.2018.028.03.01

Ritz, C. W., Fairchild, B. D., \& Lacy, M. P. (2004). Implications of ammonia production and emissions from commercial poultry facilities: a review. Journal of Applied Poultry Research, 13(4), 684-692. https:// doi.org/10.1093/japr/13.4.684

Sarjana, T., Mahfudz, L. D., Sunarti, D., Sarengat, W., Huda, N. K. F., Rahma, N. A., Renata, Suryani, D. A., Arfianta, W. F., \& Mustaqim, B. (2018). Microclimate Condition Changes Due To Zone Placement In Broiler Closed House. Seminar Nasional Kebangkitan Peternakan III: "Hilirisasi Teknologi Peternakan Pada Era Revolusi Industri 4.0," 688-700.

Selle, P. H., Ravindran, V., Pittolo, P. H., \& Bryden, W. L. (2003). Effects of phytase supplementation of diets with two tiers of nutrient specifications on growth performance and protein efficiency ratios of broiler chickens. Asian-Australasian Journal of Animal Sciences, 16(8), 1158-1164. https:// doi.org/10.5713/ajas.2003.1158

Shi, Q., Wang, W., Chen, M., Zhang, H., \& $\mathrm{Xu}$, S. (2019). Ammonia induces Treg/Th1 imbalance with triggered NF- $\kappa B$ pathway leading to chicken respiratory inflammation response.
Science of The Total Environment, 659, 354-362. https://doi.org/10.101 6/j.scitotenv.2018.12.375

Sugiharto, S., Yudiarti, T., Isroli, I., Widiastuti, E., \& Putra, F. D. (2017). Effects of feeding cassava pulp fermented with Acremonium charticola on growth performance, nutrient digestibility and meat quality of broiler chicks. South African Journal of Animal Science, 47(2), 130-138. https://doi.org/10.4314/saja s.v47i2.4

Sugito, W., Manalu, D., Astuti, E., Handharyani, \& Chairul. (2007). Efek cekaman panas dan pemberian ekstrak heksan tanaman jaloh (Salix Tetrasperma Roxb) terhadap kadar kortisol, triiodotironin dan profil hematologi ayam broiler. JITV, 12(3), 175-182.

Sulaibah, S., Sarjana, T. A., \& Murwani, R. (2019). Pengaruh perbedaan panjang kandang dan zona penempatan di dalam closed house terhadap total leukosit dan differensial leukosit ayam broiler. Agromedia, 37(1), 86-92. https://doi.org/10.47728/ag.v37i1.248

Tamzil, M. H. (2014). Stres panas pada unggas: metabolisme, akibat dan upaya penanggulangannya. Wartazoa, 24(2), 57-66.

Wahju, J. (2004). Kecernaan Protein. Gadjah Mada University Press.

Wolynetz, M. S., \& Sibbald, I. R. (1984). Relationships between apparent and true metabolizable energy and the effects of a nitrogen correction. Poultry Science, 63(7), 1386-1399. https://doi.org/10.3382/ps.0631386

Xiong, Y., Tang, X., Meng, Q., \& Zhang, H. (2016). Differential expression analysis of the broiler tracheal proteins responsible for the immune response and muscle contraction induced by high concentration of ammonia using iTRAQ-coupled 2D LC-MS/MS. Science China Life Sciences, 59(11), 1166-1176. https:// doi.org/10.1007/s11427-016-0202-8 
Yahav, S., \& McMurtry, J. P. (2001). Thermotolerance acquisition in broiler chickens by temperature conditioning early in life - the effect of timing and ambient temperaturey. Poultry Science, 80(12), 1662-1666. https:// doi.org/10.1093/ps/80.12.1662

Yahav, Shlomo. (2004). Ammonia affects performance and thermoregulation of male broiler chickens. Animal
Research, 53(4), 289-293. https:// doi.org/10.1051/animres:2004015

Zuprizal., Larbier, M., Chagneau, A. M., \& Geraert, P. A. (1993). Influence of Ambient Temperature on True Digestibility of Protein and Amino Acids of Rapeseed and Soybean Meals in Broilers. Poultry Science, 72(2), 289-295. https://doi.org/10.33 82/ps.0720289 